\title{
Mens rea in joint enterprise: a role for endorsement?
}

Article

Accepted Version

Krebs, B. (2015) Mens rea in joint enterprise: a role for endorsement? Cambridge Law Journal, 74 (3). pp. 480-504. ISSN 0008-1973 doi:

https://doi.org/10.1017/S0008197315000677 Available at https://centaur.reading.ac.uk/42081/

It is advisable to refer to the publisher's version if you intend to cite from the work. See Guidance on citing.

To link to this article DOI: http://dx.doi.org/10.1017/S0008197315000677

Publisher: Cambridge University Press

All outputs in CentAUR are protected by Intellectual Property Rights law, including copyright law. Copyright and IPR is retained by the creators or other copyright holders. Terms and conditions for use of this material are defined in the End User Agreement.

\section{www.reading.ac.uk/centaur}

\section{CentAUR}

Central Archive at the University of Reading

Reading's research outputs online 


\section{MENS REA IN JOINT ENTERPRISE: A ROLE FOR ENDORSEMENT?}

\section{Beatrice Krebs ${ }^{*}$}

Words (excl. footnotes): 9,555

Words (incl. footnotes): 13,974

\section{KEYWORDS}

Criminal Law, Joint Enterprise, Murder, Accessorial Liability, Mens Rea

\section{ABSTRACT}

This paper argues that the problems commonly associated with the joint enterprise doctrine might be alleviated by supplementing the cognitive mens rea standard of foresight with a volitional element that looks to how the defendant related to the foreseen risk. A re-examination of the case law suggests that a mens rea conception of foresight plus endorsement might be within interpretative reach. The paper considers possible objections to such a development but ultimately rejects them. It concludes that it is not necessary to wait for Parliament to put in place reforms: joint enterprise is a creature of the common law, and the common law is able to tame it unaided.

\section{INTRODUCTION}

Two individuals, $\mathrm{P}$ and $\mathrm{S}$, are engaged in the burglary of V1's house. They gain access by prying open the back door with a metal bar which $\mathrm{P}$ then continues to carry with him. When surprisingly they come across the householder, P fears that V1's cries for help will alarm the neighbours. To silence him, he hits V1 forcefully on the head

\footnotetext{
${ }^{*}$ Lecturer, School of Law, University of Reading. My thanks to Andrew Ashworth and Nicola Lacey for their comments on an earlier draft of this article. I am also indebted to the members of the Oxford Criminal Law Discussion Group and my colleagues at Reading who gave valuable feedback when I presented some of my ideas to them. I am also grateful to the AHRC for funding the research which led to this article.
} 
with the metal bar, realising that in doing so he is virtually certain to cause V1 serious harm. V1 dies of his injuries. ${ }^{1}$

Later that day, $\mathrm{P}$ and $\mathrm{S}$ take part in a fight between rival gangs. While $\mathrm{S}$ expects a fist fight aimed at 'teaching' their rivals 'a lesson', he is aware that $\mathrm{P}$, whom he now knows to be of a violent disposition, is still carrying the metal bar. As things become more heated, P uses the bar to hit V2 ferociously on the head. V2 dies.

There is little doubt that $\mathrm{P}$ has committed murder in both instances. He has caused the death of another person with the requisite mental state for murder: as was confirmed in Woollin, ${ }^{2}$ murder does not require that the murderer act with intent to kill. It is sufficient that the act of killing was done with intent to inflict serious injury. ${ }^{3}$

But what about $\mathrm{S}$ ? Is he also guilty of murder? On both occasions, $\mathrm{P}$ and $\mathrm{S}$ were jointly involved in a criminal venture (burglary, assault). They were associates in crime. However, on neither occasion had they set out to commit murder specifically. If murder had been on their minds, there would be little difficulty in holding them both to account for V1's and V2's deaths: $\mathrm{P}$ as the perpetrator and $\mathrm{S}$ as a secondary party on the basis of aiding and abetting contrary to s. 8 of the Accessories and Abettors Act 1861 (for S encouraged P to kill V1 and V2). ${ }^{4}$

In the above examples things are different, however, in that the purpose crime (burglary, assault) differs from the one that $\mathrm{P}$ and $\mathrm{S}$ are now accused of (murder). In a deviation from their common plan or purpose (burglary, assault), $\mathrm{P}$ has killed another

\footnotetext{
${ }^{1}$ Similar examples are discussed in Hyde [1991] 1 Q.B. 134 (CA) 138D and Gnango [2011] UKSC 59, [2012] 1 A.C. 827 at [14].

2 [1999] 1 A.C. 81 (HL).

${ }^{3}$ Cunningham [1982] A.C. 566 (HL).

${ }^{4}$ See Rahman [2008] UKHL 45, [2009] 1 A.C. 129 at [33] (Lord Rodger): '[I]f A and B agree to kill their victim and proceed to attack him with that intention, they are both guilty of murder, irrespective of who struck the fatal blow. In Lord Hoffmann's words (Brown v The State [2003] UKPC 10, para $13)$, they are engaged in a "plain vanilla" joint enterprise.'
} 
person, albeit that each murder was committed on the occasion of, and hence incidentally to, carrying out the purpose crime.

The issue thus raised by the above examples is whether $\mathrm{S}$ is liable for a murder committed by $\mathrm{P}$ incidentally to their joint criminal venture (which was aimed at the commission of a crime other than murder). English common law gives an affirmative answer to this question, provided that $S$ was engaged in the joint criminal enterprise realising that $\mathrm{P}$ might commit murder as a corollary offence (which requires $\mathrm{S}$ to have foreseen that $\mathrm{P}$ might attack $\mathrm{V} 1$ and $\mathrm{V} 2$ with the requisite mens rea, i.e. intent to kill or to cause them serious personal injury). ${ }^{5}$

In the case law, the purpose crime is commonly referred to as 'crime A' and the incidental crime as 'crime B', ${ }^{6}$ while the imposition of liability on S for P's crime B has come to be known as the doctrine of joint enterprise ${ }^{7}$ or parasitic accessory liability. ${ }^{8}$ Most agree that, while of great importance in practice, this doctrine is far from satisfactory: most academic commentary portrays it in overwhelmingly negative terms. ${ }^{9}$ Even the courts, while insisting it is still good law, find the principle wanting in some respects. ${ }^{10}$ While the Law Commission and the House of Commons Justice

\footnotetext{
${ }^{5}$ Powell [1999] 1 A.C. 1 (HL); Rahman [2008] UKHL 45, [2009] 1 A.C. 129; Mendez and Thompson [2010] EWCA Crim 516, [2011] Q.B. 876; A and others [2010] EWCA Crim 1622, [2011] Q.B. 841; Stringer [2011] EWCA Crim 1397, [2012] Q.B. 160; Carpenter [2011] EWCA Crim 2568; Gnango [2011] UKSC 59, [2012] 1 A.C. 827; Jogee [2013] EWCA Crim 1433; Odegbune [2013] EWCA Crim 711; Winston and Collins [2015] EWCA Crim 524.

${ }^{6}$ Gnango [2011] UKSC 59, [2012] 1 A.C. 827 at [42] (Lord Phillips PSC and Lord Judge CJ); A and others [2010] EWCA Crim 1622, [2011] Q.B. 841 at [27] (Hughes LJ).

${ }^{7}$ G. Virgo, "The doctrine of joint enterprise liability" (2010) Archbold Review 6.

${ }^{8}$ The Supreme Court adopted this term (coined by Professor Sir John Smith) in Gnango [2011] UKSC 59, [2012] 1 A.C. 827 at [15].

${ }^{9}$ See e.g. C.M.V. Clarkson, "Complicity, Powell and manslaughter" [1998] Crim. L.R. 556, 557-558; G. Virgo, "The doctrine of joint enterprise liability" (2010) Archbold Review 6, 9; G. Virgo, "Joint enterprise liability is dead: long live accessorial liability" [2012] Crim. L.R. 850, 854; W. Wilson and D. Ormerod, "Simply harsh to fairly simple: joint enterprise reform" [2015] Crim. L.R. 3, 5-21; B. Crewe and others, "Joint enterprise: the implications of an unfair and unclear law" [2015] Crim. L.R. 252-269.

${ }^{10}$ Powell [1999] 1 A.C. 1 (HL) 11 (Lord Mustill), 25 (Lord Hutton).
} 
Committee have recommended statutory reform as a matter of some urgency, ${ }^{11}$ successive Justice Secretaries have expressed little enthusiasm for following this advice. ${ }^{12}$ It therefore now seems rather unlikely that the doctrine will be reformed by statute, so that, if change is to happen, it is for the courts to bring this about. The Supreme Court has just agreed to hear the appeal in the joint enterprise murder case of Jogee. ${ }^{13}$ The hearing will take place later this year and presents the Supreme Court with an opportunity fundamentally to review the law in this area. Against this backdrop, this article will explore whether the contentious features of the joint enterprise principle could be improved by way of common law development.

On one view, now dominant in the case law, ${ }^{14}$ joint enterprise represents a distinct, judge-made form of liability for participants in crime which exists alongside aiding and abetting under s. 8 of the Accessories and Abettors Act 1861 and joint perpetration. In other words, it is used as a principle of inculpation. I have argued elsewhere that, both as a matter of history and principle, it is preferable to regard it as a principle of exculpation, delineating the boundaries of liability for aiding and abetting and joint perpetration. ${ }^{15}$ On either view, the threshold for liability as it is

\footnotetext{
${ }^{11}$ Law Commission, Murder, Manslaughter and Infanticide - Project 6 of the Ninth Programme of Law Reform: Homicide (Law Com No 304, 2006); Law Commission, Participating in Crime (Law Com No 305, 2007); House of Commons Justice Committee, Joint Enterprise - Eleventh Report of Session 2010-12, vol I (HC 1597, 2012); House of Commons Justice Committee, Joint Enterprise: follow-up - Fourth Report of Session 2014-15 (HC 310, 2014).

${ }^{12}$ Kenneth Clarke indicated that the Committee's recommendations in relation to consulting on new legislation would not be taken up in the foreseeable future, see http://www.publications.parliament.uk/ $\mathrm{pa} / \mathrm{cm} 201012 / \mathrm{cmselect} / \mathrm{cmjust} / 1901 / 190104 . \mathrm{htm}$ (accessed 21 May 2015). Chris Grayling was even less sympathetic, see http://www.publications.parliament.uk/pa/cm201415/cmselect/cmjust/1047/ 104704.htm (accessed 21 May 2015).

13 [2013] EWCA Crim 1433. See https://www.supremecourt.uk/docs/permission-to-appeal-20150102.pdf (accessed 21 May 2015).

${ }^{14}$ A and others [2010] EWCA Crim 1622, [2011] Q.B. 841 at [9-10]; Gnango [2011] UKSC 59, [2012] 1 A.C. 827 at [93]. See also CPS Guidance on: Joint Enterprise Charging Decisions, available at http://www.cps.gov.uk/legal/assets/uploads/files/Joint_Enterprise.pdf (accessed 21 May 2015).

${ }^{15}$ B. Krebs, "Joint Criminal Enterprise" (2010) 73(4) M.L.R. 578-604. On this understanding of how the concepts of co-perpetration, aiding \& abetting and joint enterprise relate to one another, there are only two ways in which an individual can become complicit in someone else's crime: joint perpetration
} 
currently understood is very low in that the accomplice is convicted on the basis of foresight alone. In contrast to a co-perpetrator or 'ordinary' accessory (who aids, abets, counsels or procures P's crime), those charged under the doctrine of joint enterprise will not have actively participated in or assisted or encouraged the commission of P's crime B. If joint enterprise is an independent head of liability, it thus threatens to subvert the stricter requirements of the other two heads of liability (which require active involvement with intent and knowledge of the essentials of the crime). If it is not an independent head of liability, but forms part of aiding and abetting and co-perpetration, it waters down the requirements of these forms of participation. On either view, the doctrine of joint enterprise is problematic because it sets the threshold for conviction lower in the case of the killer's associate than in the case of the actual killer. ${ }^{16}$ In other words, it is easier to prove murder against the person who just stood by and watched than the person who struck the fatal blow. The principle leads to particularly harsh results in the context of murder because of the mandatory life sentence for those who are convicted of this offence. ${ }^{17}$

In 2003, Antje Pedain suggested that a concept of endorsement might be helpful in understanding the conception of intention in the law of murder and presented a powerful argument that such an approach was already evident in Lord Hailsham's speech in Hyam. ${ }^{18}$ She argued that intention in its primary sense of purpose and in its secondary sense of foresight of a consequence as virtually certain, rather than being conceptually independent, have a common denominator in that they

and aiding \& abetting. Joint enterprise only comes into play to determine the scope of either head of liability. In this, it fulfils a necessary and important function.

${ }^{16}$ See Law Commission, Consultation Paper No. 131, Assiting and Encouraging Crime (1993), para [2.123]; M. Dyson, "More appealing joint enterprise” (2010) C.L.J. 425.

${ }^{17}$ B. Crewe and others, "Joint enterprise: the implications of an unfair and unclear law" [2015] Crim. L.R. 252, 255-268.

${ }^{18}$ A. Pedain, "Intention and the Terorrist Example" [2003] Crim. L.R. 579, 593. 
both 'signal prior endorsement of the outcome by the actor, leaving no room for the actor to meaningfully disassociate himself from the outcome once it has materialised. ${ }^{, 19}$ Using Woollin $^{20}$ - a despairing father threw his crying baby son towards his pram, causing him to hit a hard surface, thus suffering fatal injuries - as an example, Pedain explained that ' $[\mathrm{t}]$ he reason why we allow Woollin to distance himself from the foreseeable consequences of his actions is that he did not endorse injury or death even as a possibility. We allow him to deny endorsement, which we may not be prepared to do in any case of merely possible as opposed to virtually certain consequences. $^{, 21}$

Though widely cited, the idea put forward in her paper is still awaiting recognition by the courts. It may well be that it was either ahead of its time, or too ambitious, or both. I would like to argue that a similar suggestion might well fall on more fertile ground in the context of joint enterprise. The secondary party is not himself 'wielding the knife'; in fact, there is little, if any, causative link between his conduct and the victim's death: it is typical of joint enterprise situations that while $\mathrm{S}$ has participated with $\mathrm{P}$ in the commission of one particular offence (crime $\mathrm{A}$ ), the killing (crime B) is carried out by $\mathrm{P}$ without any further acts of assistance or encouragement on S's part. ${ }^{22}$ It may therefore be easier for a court to move from a foresight to an endorsement test in this more limited context than in the general law of murder - which is not to say that such a more radical step might not be taken in due course.

\footnotetext{
${ }^{19}$ Ibid., at 586.

${ }^{20}$ [1999] 1 A.C. 82 (HL).

${ }^{21}$ A. Pedain, "Intention and the Terorrist Example" [2003] Crim. L.R. 579, 586.

${ }^{22}$ G.R. Sullivan, "The Law Commission Consultation Paper on complicity: Part 2: Fault elements and joint enterprise" [1994] Crim. L.R. 252, 261. See also G. Virgo, "Joint enterprise liability is dead: long live accessorial liability" [2012] Crim. L.R. 850, 858-860.
} 
In the joint enterprise context, an endorsement-based approach might reduce the risks of uncertainty and inconsistency ${ }^{23}$ that stem from the possibility that, under the law as it stands, some juries may limit their deliberations strictly to the foresight criterion whilst others may take a more holistic approach in assessing the defendant's mental state. It would also bring the relevant mens rea standard (some form of subjective recklessness) ${ }^{24}$ closer to one of intention and thus alleviate concerns that the current law may be over-inclusive and setting the hurdle for conviction too low, especially where $\mathrm{S}$ is charged with crimes such as murder that for $\mathrm{P}$ require proof of intent: $^{25}$ the underlying idea of endorsement is that it is ultimately S's accepting mindset (when it comes to crime B) that is reprehensible and attracts blame, not the fact that $\mathrm{S}$ had a (possibly fleeting) realisation of the fatality as such (coupled with the fact of his continued participation in crime A). S's accepting mind-set, in other words, supplies the necessary mental element to settle him with liability as an accessory to or joint perpetrator of crime B. Such endorsement might manifest itself, for example, by S communicating his assent to third parties before or during the commission of crime $\mathrm{B} ;{ }^{26}$ by showing acquiescence or reconciliation (falling short of encouragement ${ }^{27}$ to

\footnotetext{
${ }^{23}$ The House of Commons Justice Committee heard (anecdotal) evidence to the effect that the current law is applied inconsistently. But as its report points out, this evidence is difficult to verify in the absence of official statistics. The Committee has recommended that the relevant data be collected in future, see House of Commons Justice Committee, Joint Enterprise - Eleventh Report of Session 201012, vol I (HC 1597, 2012) 3 at pp. 10-11.

${ }^{24}$ Powell [1999] 1 A.C. 1 (HL) 14 (Lord Steyn). S's mental state, falling short of intention (even in the oblique sense) must be one of subjective recklessness. However, it can be doubted whether this amounts to Cunnigham-recklessness. Jury directions focus on S's foresight; foresight is not synonymous with recklessness in the Cunningham-sense which requires the defendant consciously to have taken an unreasonable risk. This latter limb is conspicuously absent in cases decided under joint enterprise principles. See also A. Ashworth and J. Horder, Principles of Criminal Law, 7th ed. (Oxford 2013) at p. 439: 'Thus the basis of joint enterprise liability is now a restricted form of (subjective) recklessness, similar in spirit to the Maxwell decision'.

${ }^{25}$ On these and related concerns see most recently The Bureau of Investigative Journalism, Joint Enterprise - An investigation into the legal doctrine of joint enterprise in criminal convictions (April 2014) at pp. 23-31.

${ }^{26}$ E.g. text messages sent from the scene of crime B.
} 
the foreseen consequences; ${ }^{28}$ or by evidence of subsequent approval, either verbal or conclusive, from which endorsement at the time the crime was committed can be inferred. $^{29}$

Ultimately, it is hoped that the suggested approach might produce fewer controversial convictions: the prosecution would need to persuade the jury that $S$ acted with a particular blameworthy mind-set, in addition to having participated in crime A with foresight of the relevant risk, the commission of crime B. Since it seems unlikely that legislative reform of the law on participation-in-crime will be achieved any time soon, ${ }^{30}$ the proposed modification of the mental element in joint criminal enterprise would have the additional benefit that it can be put into practice through evolution of the common law, as will be explained below.

This paper will first set out the current mens rea element in joint enterprise and briefly reiterate how it can lead to inconsistency, incoherence and injustice. The main part of the article puts forward the suggested alternative of focusing on S's attitude (endorsement) towards P's further crime as opposed to his mere foresight of that crime and explains why this would be preferable to the law as it stands. It considers possible objections to such a development and explains how these might be overcome. The paper concludes that in some of the seminal cases on joint enterprise the law has come surprisingly close to an endorsement-focussed approach which might therefore be adopted by the courts without legislative intervention.

\footnotetext{
${ }^{27}$ Arguably, Odegbune [2013] EWCA Crim 711 is a case of this kind: although S had orchestrated the event (a fight between rival groups), he was chasing another boy at the time of the murder and so did not actually encourage the killing of V. However, it is arguable that his overall conduct shows not just foresight, but endorsement of the possibility of the fight turning lethal.

${ }^{28}$ E.g. filming of P's commission of crime B.

${ }^{29}$ For an example see Broda (CA, 25 March 2015, unreported): S bought Ps a beer after the assault.

${ }^{30}$ See above, n 12.
} 


\title{
II. THE BLunT TOOL OF THE FORESIGHT TEST
}

Where joint enterprise principles are brought into play, ${ }^{31}$ the applicable mens rea standard will, in essence, be one of foresight [of P's murder] (rather than foresight plus an intention to aid \& abet [P's murder], normally required to prove aiding \& abetting, or intention [to inflict really serious harm], normally required to support a charge of principalship): ${ }^{32}$ while the Supreme Court stressed in Gnango that mens rea in joint enterprise actually requires both ' $a$ common $^{33}$ intention to commit crime A' and foresight by $\mathrm{S}$ of the possibility that $\mathrm{P}$ might commit crime $\mathrm{B},{ }^{34}$ the common intention to commit crime $\mathrm{A}$ is usually not hard to find. ${ }^{35}$ Liability for $\mathrm{S}$ thus essentially turns on whether the jury believes he had foresight of P's commission of crime B. This is an unsatisfactory standard of assessing liability in joint enterprise

\begin{abstract}
${ }^{31}$ The Court of Appeal suggests that there are three categories of case in which resort is had to the term joint enterprise, see $A$ and others [2010] EWCA Crim 1622, [2011] Q.B. 841 (CA) at [7], 845 (Hughes LJ): '(i) Where two or more people join in committing a single crime, in circumstances where they are, in effect, all joint principals (...). (ii) Where D2 aids and abets D1 to commit a single crime (...). (iii) Where D1 and D2 participate together in one crime (crime A) and in the course of it D1 commits a second crime (crime B) which D2 had foreseen he might commit.' Likewise Toulson LJ in Stringer [2011] EWCA Crim 1396, [2012] Q.B. 160 (CA) at [57]. D. Ormerod (ed) subdivides these categories still further and identifies five joint enterprise situations: see Smith and Hogan's Criminal Law, 13th ed. (Oxford 2011) at p. 213. There is thus no settled taxonomy of joint enterprise cases. See also R. Fortson QC, "Inchoate Liability and the Part 2 Offences under the Serious Crime Act 2007" in A. Reed and M. Bohlander (eds), Participation in Crime - Domestic and Comparative Perspectives (Farnham, Surrey, UK; Burlington, VT 2013) 173 at p. 202: '[I]t is doubtful that there is consensus among criminal law practitioners as to what "joint enterprise" means.'
\end{abstract}

\footnotetext{
${ }^{32}$ Kirby J in Clayton v The Queen (2006) 168 A. Crim. R. 174 at [63].
}

${ }^{33}$ This choice of terminology - common rather than joint intention - is potentially misleading: a joint enterprise requires concerted action on the basis of an understanding that is shared between the actors. To describe an intention as common (to two or more actors) might suggest that it can be held concurrently, i.e. individually, without one actor being aware that the other has the same intention.

${ }^{34}$ Gnango [2011] UKSC 59, [2012] 1 A.C. 827 (SC) at [42] (Lord Phillips and Lord Judge).

${ }^{35}$ See for example Badza [2009] EWCA Crim 2695 at [32-33]: Sir Anthony May described the joint enterprise as 'a late night outing together which, as the appellant must have foreseen, might result in their participation in violence during which [the principal offender] (...) might use the knife aggressively with the requisite intent for murder.' Such a loosely circumscribed venture (crime A) is not a particularly strong candidate to bear the load of S's conviction, especially where P's offence (crime B) constitutes murder. In fairness to his Lordship, it becomes clear later in his judgment that he does not think that a 'late night outing', not being criminal in itself, can ever constitute 'crime A' for the purposes of joint enterprise. The quote nevertheless demonstrates that we are on a slippery slope. It does indeed not take much to infer an agreement to commit a crime, and this becomes clear in the judge's directions to the jury expressly approved by his Lordship. Thus, the judge said that 'agreement to commit an offence may arise on the spur of the moment. Nothing needs to be said at all. An agreement can be inferred from the behaviour of the parties'. 
cases, because in contrast to (straightforward) cases of (co-) perpetration or aiding \& abetting, $\mathrm{S}$ has neither contributed to the actus reus of the offence he is charged with, nor has he directly ${ }^{36}$ helped with or encouraged that crime. ${ }^{37}$ The mental element foresight of a possibility - thus has to do all the work linking S to P's crime B. The rather undemanding actus reus stage ${ }^{38}$ is not counter-balanced, as one might have expected, by a particularly demanding mens rea requirement. Apart from concerns that the prosecution's case of foresight may be made on the basis of rather weak evidence (turning on signs of association and gang membership), ${ }^{39}$ which do not concern the (in)adequacy of the substantive legal rules with which this paper is concerned, the foresight criterion on its own fails to make some (morally) significant distinctions which the law, arguably, ought to reflect. ${ }^{40}$ One possible consequence is that participants that are very much on the periphery of events are treated on a par with the main perpetrators. ${ }^{41}$ Where crimes of violence are concerned (as is usually the case where joint enterprise is invoked), escalation is always a possible, and hence

\footnotetext{
${ }^{36}$ Although the mere fact that $\mathrm{S}$ participated in crime A when he had foresight of crime B being possibly committed by his associate is said to amount to assistance and encouragement of crime B.

${ }^{37}$ In Mendez and Thompson [2010] EWCA Crim 516 at [18-23] and Stringer [2011] EWCA Crim 1396, [2012] Q.B. 160 at [47-51] Toulson LJ suggested that in such cases, S's liability is based on a broad concept of causation.

${ }^{38}$ An implied agreement between $\mathrm{P}$ and $\mathrm{S}$ to commit crime A seems to suffice.

${ }^{39}$ See evidence given by Tim Moloney QC and Simon Natas, cited in House of Commons Justice Committee, Joint Enterprise - Eleventh Report of Session 2010-12, vol I (HC 1597, 2012) at p. 8. The CPS Guidance on: Joint Enterprise Charging Decisions, available at http://www.cps.gov.uk/legal/assets/uploads/files/Joint_Enterprise.pdf (accessed 21 May 2015), issued in December 2012 in response to concerns raised in front of the House of Commons Justice Committee, now states that 'without some participation by $\mathrm{D}(. .$.$) association with or membership of a$ group or gang' is insufficient to support a charge of joint enterprise (at [36]) and that 'D's association with P or a gang cannot, on its own, make D complicit in a joint enterprise' (at [46]). However, according to [48-49] '[t] here are many ways in which D's links with P or a group or gang can form part of the circumstantial evidence in a case. (...) Where such association evidence is relied on, the circumstances of the association of $\mathrm{D}$ with $\mathrm{P}$, together with the other evidence in the case, must give rise to the inference that D was assisting or encouraging P's offence.'

40 On the (contested) idea that criminal liability is to be ascribed in accordance with moral responsibility, see R.A. Duff, Intention, Agency \& Criminal Liability (Oxford 1990) at pp. 103-104 (with reference to R.A. Duff, Trials and Punishment (Cambridge 1986) chs 3-4).

${ }^{41}$ See the case studies in The Bureau of Investigative Journalism, Joint Enterprise - An investigation into the legal doctrine of joint enterprise in criminal convictions (April 2014) at pp. 19-31.
} 
foreseeable, consequence. It is thus difficult for a defendant to escape liability on the basis that he did not actually foresee that the harm anticipated might result in much greater, and ultimately fatal, harm. We may feel that someone who does not disassociate himself from violent events before they turn really nasty is rightly caught by the net of liability if death results (even though not at his, but someone else's hands). But is this true under all circumstances? And is it right to hold him liable for murder, carrying a mandatory life sentence?

S may have quite different reasons for his continued association with the enterprise:

(1) Maybe he genuinely, albeit naively, believes that his presence might help to avoid the worst, in the sense that he trusts his being there might have a moderating influence on others, although he can foresee that there is still a (significant) risk that one of his associates may do V serious harm.

(2) Maybe he does not care what happens, does not care whether the potential victim, $\mathrm{V}$, lives or dies.

(3) Maybe he desires events to unfold as they then do.

In all these instances, he remains associated with the enterprise, and does so with the requisite level of foresight (of death as a possibility) ${ }^{42}$; yet his attitude towards the harm foreseen differs markedly in the three scenarios:

(1) In the first instance, S remains involved precisely because he wants to reduce the likelihood that $\mathrm{V}$ is seriously hurt.

(2) In the second example, $\mathrm{S}$ is indifferent as to whether $\mathrm{V}$ is caused serious harm or not.

\footnotetext{
${ }^{42}$ Some raise the question whether the foresight element does even have to relate to death as opposed to acts committed by $\mathrm{P}$ with the intention of killing or causing GBH by those acts, see W. Wilson and D. Ormerod, "Simply harsh to fairly simple: joint enterprise reform" [2015] Crim. L.R. 3, 5-6.
} 
(3) In the final scenario, $S$ positively wants $V$ to be seriously harmed.

People generally would think worse of S in scenario (2) than in scenario (1), and still worse in scenario (3). The intuitively recognised differences in attitude reflect differences in moral culpability, which, it is suggested, ought to translate to differences in criminal responsibility.

There may be cases in which the same evidence suggests both that S clearly foresaw the ensuing violence and that he was not 'okay' with it. They demonstrate particularly clearly that focusing on foresight alone cannot be correct. P and S agree to 'torch' some cars. P has a propensity for violence and usually carries a knife, as S knows, but using violence is not part of their plan. The two succeed in setting alight a Mercedes and are in the process of 'torching' a BMW when a local resident, V, comes upon the scene and threatens to call the police. Fearing apprehension, $\mathrm{P}$ fatally stabs V. What impact on S's liability would the following alternative findings have?

(1) S was happy to come along even though he foresaw the risk that someone might get hurt.

(2) S only agreed to come along if $\mathrm{P}$ promised that no one would get hurt.

It is clear that there is more evidence of foresight in scenario (2) than in scenario (1). At the same time, S's (moral) culpability is lower in the second case than in the first. This is because extracting the promise from $\mathrm{P}$ that no one will get hurt is good evidence not just of foresight (that $\mathrm{P}$ may hurt someone) but also of the attitude that $\mathrm{S}$ has towards the harm caused by P. In the second example, S does not want anyone to be harmed; in the first example, he is indifferent to harm being caused: $\mathrm{S}$ is 'happy' to come along, although he can foresee that P's propensity for violence might result in someone being injured. S's attitude (of 'so be it') towards the fatal outcome produced by $\mathrm{P}$ is blameworthy, not his foresight of the fatality as such (albeit coupled with the 
fact that he remains associated with $\mathrm{P}$ ). The two cases illustrate a morally relevant distinction which the current law does not acknowledge: as soon as $\mathrm{S}$ foresees that $\mathrm{P}$ might kill with the requisite murderous intention, he is put on a par with $\mathrm{P}$ and becomes liable to a conviction for murder should $\mathrm{P}$ indeed kill with the requisite intention (i.e. with foresight of grievous bodily harm or death as a virtual certain consequence of his, P's, actions) ${ }^{43}$ the alternative of a manslaughter conviction ${ }^{44}$ is currently only relevant where S foresees violence on P's part, but does not expect him to harbour murderous intentions in the Woollin-sense. Assuming $\mathrm{S}$ does indeed contemplate that $\mathrm{P}$ might act with lethal mens rea in the two situations described above, the current law would allow a jury to convict him of murder in both instances. Such an outcome seems fundamentally unjust, ${ }^{45}$ even if we take into account that in scenario (2) $\mathrm{S}$ is not entirely innocent: he has demonstrated a less than full commitment to the avoidance of harm; ${ }^{46}$ if he wanted to err on the safe side, he could have chosen to stay behind. However, he is not on a par with the actual killer: to be convicted of murder, a person needs to cause death with intention (at least) to do really serious personal injury. S's contribution (if any) does not amount to a but for

\footnotetext{
${ }^{43}$ Rahman [2008] UKHL 45, [2009] 1 A.C. 129 at [36] (Lord Rodger).

${ }^{44}$ While Powell [1999] 1 A.C. 1 (HL), which was not entirely clear on this point, has been taken to mean that joint enterprise is an all or nothing approach (resulting either in a murder conviction or acquittal) - for a recent example see Mendez and Thompson [2010] EWCA Crim 516 at [21]-[22], [38] (Toulson LJ) - Carpenter [2011] EWCA Crim 2568, [2012] Q.B. 722 (CA) now clarifies that in appropriate cases the defendant may still be charged with murder and manslaughter in the alternative. This is in line with dicta in Yemoh [2009] EWCA Crim 930, which was heard in the Court of Appeal after Powell, and reconfirms pre-Powell Court of Appeal decisions such as Roberts [2001] EWCA Crim 1594, which support the view that someone, who takes part in an joint venture realising that this will involve some degree of violence, will usually be guilty of (unlawful dangerous act) manslaughter (or murder, if he had the requisite mens rea), if death results.
}

${ }^{45}$ Likewise Kirby J in Clayton v The Queen (2006) 168 A. Crim. R. 174 at [98]. See also R. Fortson QC, "Inchoate Liability and the Part 2 Offences under the Serious Crime Act 2007" in A. Reed and M. Bohlander (eds), Participation in Crime - Domestic and Comparative Perspectives (Farnham, Surrey, UK; Burlington, VT 2013) 173 at p. 203: ' $[\mathrm{I}] \mathrm{t}$ is submitted that persons ought not to be stigmatised as "murderers", and sentenced as such, on mere foresight of what another might do.'

${ }^{46}$ G.R. Sullivan, "Participating in crime: Law Com No 305 - Joint criminal ventures" [2008] Crim. L.R. 19, 29. 
cause of the victim's death, nor does his level of foresight of murder as a possibility allow for a finding of intention in the Woollin-sense.

That S's culpability in joint enterprise situations rarely equals P's was acknowledged by the late Lord Mustill in his speech in Powell. ${ }^{47}$ Moreover, his Lordship was unhappy that the foresight test ties itself into (conceptual) knots over scenario 2 of the 'car torching' example. Thus he said:

In one particular situation there is, however, a problem which [joint enterprise] cannot solve. Namely, where $\mathrm{S}$ foresees that $\mathrm{P}$ may go too far; sincerely wishes that he will not, and makes this plain to P; and yet goes ahead, either because he hopes for the best, or because $\mathrm{P}$ is an overbearing character, or for some other reason. Many would say, and I agree, that the conduct of $\mathrm{S}$ is culpable, although usually at a lower level than the culpability of the principal who actually does the deed. Yet try as I may, I cannot accommodate this culpability within a concept of joint enterprise. How can a jury be directed at the same time that $\mathrm{S}$ is guilty only if he was party to an express or tacit agreement to do the act in question, and that he is guilty if he not only disagreed with it, but made his disagreement perfectly clear to P? Are not the two assertions incompatible? ? $^{48}$

It is certainly true that the two assertions are contradictory; nonetheless, under the law as it stands, such a case would be covered by the joint enterprise doctrine. As Lord Rodger confirmed in Rahman if 'B contemplates that A may take a gun and use it in

\footnotetext{
${ }^{47}$ [1999] 1 A.C. 1 (HL) 11: 'Many would say, and I agree, that the conduct of S is culpable, although usually at a lower level than the culpability of the principal who actually does the deed.'

${ }^{48}$ Powell [1999] 1 A.C. 1 (HL) 11.
} 
the course of the attack on the victim [then], even if B is vehemently opposed to the use of a gun and tries to dissuade A from carrying one, nevertheless, if, being aware of the risk, B takes part in the joint assault, he will be guilty of murder if A shoots the victim' ${ }^{49}$ In covering this case, joint enterprise is not just over-inclusive ${ }^{50}$ and counter-intuitive, it is also conceptually unsound.

The problem is compounded by the rule that, in English law, duress is not a defence to murder. ${ }^{51}$ Returning to our 'car torching' example, imagine a young, aspiring member of the 'car torching' gang who is seriously worried about himself becoming a victim if he refuses to come along when it becomes clear that violence against people rather than cars is very much on the cards. The current foresight test renders him liable to be convicted of murder, and the fact that he was, or believed that he was, under duress in failing to disassociate himself from the violence that ensued will not assist him. Such a case of coercion would be a fortiori the case mentioned by Lord Mustill in which S only stays on the scene because P is an 'overbearing character, ${ }^{52}$ It may be just about arguable that a person who himself actively brought about another person's death, or actively assisted another in killing, should be barred from the defence if he did so under coercion. ${ }^{53}$ I would argue that it is quite a different

\footnotetext{
${ }^{49}$ Rahman [2008] UKHL 45, [2009] 1 A.C. 129 at [36].

${ }^{50}$ Similar in outcome, if not reasoning, G. Virgo in "Joint enterprise liability is dead: long live accessorial liability" [2012] Crim. L.R. 850, 862: '[S] should not then be convicted of crime B, because his explicit rejection of it means that he is not associated with it.' See also B. Mitchell, "Participating in Homicide" in A. Reed and M. Bohlander (eds), Participation in Crime - Domestic and Comparative Perspectives (Farnham, Surrey, UK; Burlington, VT 2013) 7 at p. 13: 'Supporters [of an increased dangerousness rationale for joint enterprise liability] would presumably argue that if [S] and $\mathrm{P}$ agree that a burglary be committed and, having expressed his opposition to any violence, [S] continues with the venture, he cannot then exclude his liability for violence because he still chose to take the risk (that the level of criminality might increase). The problem with this argument is that it is too open-ended.'

${ }^{51}$ Howe [1987] AC 417 (HL); Gotts [1992] 2 AC 412 (HL).

${ }^{52}$ Powell [1999] 1 A.C. 1 (HL) 11.

${ }^{53}$ Though the Law Commission notes that '[a]lmost all our consultees were agreed that duress should be a defence to murder in some manner or form', see Murder, Manslaughter and Infanticide - Project 6 of the Ninth Programme of Law Reform: Homicide (Law Com No 304, 2006), para. [1.56].
} 
thing to find someone who was merely on the periphery of events and not actively involved guilty of murder in circumstances where he remained at the scene out of fear or intimidation.

\section{FORESIGHT PLUS ENDORSEMENT?}

Arguably the law on joint enterprise would be less controversial (and fewer cases might reach the appellate courts) if it allowed for more subtle distinctions to be drawn when it comes to S's mind-set. ${ }^{54}$ This might be achieved if, in assessing the defendant's mental state, the focus shifted from foresight of the consequences (cognitive standard) to foresight plus endorsement of the consequences foreseen (cognitive-volitional standard). In what follows, I will explore what such an approach might look like and how it would fit in with the general framework of the common law. ${ }^{55}$ It will be argued that an attitude-oriented approach towards assessing mens rea in joint enterprise might already be within interpretative reach of the common law: some (pre-Powell) cases can be read as presaging an element of approval or endorsement as to P's conduct (which $\mathrm{S}$ has foreseen as a possible incident to their joint venture), while more recent ones are at least ambiguous on this point. Indeed, it is arguable that, in the same way that foresight (albeit in the degree of virtual

\footnotetext{
${ }^{54}$ It might be objected that introducing greater subtleties into the jury direction will lead to more scope for appeals. However, ultimately this is an argument premised on an inherent lack of confidence in the jury system. The Law Commission has recently consistently proposed that more gradations of criminal culpability should be introduced. It could also be argued that the recent abundance of appeals from joint enterprise convictions is a function of a (possibly rightly) perceived mismatch between the crude test of foresight and the ordinary person's intuitive moral judgment. It might also be objected that differences in responsibility should be dealt with at the sentencing rather than conviction stage. This raises a more general issue of criminal law - why have gradations of responsibility reflected at the offence stage at all (eg murder versus manslaughter) rather than dealing with them at the sentencing stage?

${ }^{55}$ On the significance of one's attitude to one's actions, see also e.g. R.A. Duff, Intention, Agency \& Criminal Liability (Oxford 1990) at pp. 149, 157-173 (recklessness as 'practical indifference') and the discussion of Duff's view in A. Norrie, Crime, Reason and History - A Critical Introduction to Criminal Law (London 1993) at pp. 71-72.
} 
certainty) can be used as evidence of intention in the general law of murder, ${ }^{56}$ foresight (of crime B) in the context of joint enterprise is similarly used to infer approval or endorsement on the part of S. The problem is that this has been lost sight of, as will be explained below, with foresight taking on a life of its own as a substantive rather than an evidential role. ${ }^{57}$

The starting point for our analysis is the realisation that statements about the mental element in joint enterprise do not speak with one voice ${ }^{58}$ they are, at least, ambivalent on what exactly is required. As such, there are some cases which, in establishing S's liability, have focussed (almost) exclusively on whether $\mathrm{S}$ contemplated or foresaw that $\mathrm{P}$ might commit crime B as a possibility. ${ }^{59}$ Others, by contrast, seem to have required such foresight plus an additional element (such as 'agreement' ${ }^{60}$, 'authorisation' ${ }^{61}$ or 'wrongful participation in face of a known risk' ${ }^{62}$ ) which, arguably, connotes endorsement, not just contemplation, of the foreseen offence. Most cases, however, appear equivocal on the issue, in that they contain

\footnotetext{
${ }^{56}$ See Woollin [1999] 1 AC 82 (HL); Matthews and Alleyne [2003] EWCA Crim 192, [2003] 2 Cr. App. R. 30 at [43-45] (Rix LJ): 'In our judgment, however, the law has not yet reached a definition of intent in murder in terms of appreciation of a virtual certainty....'

${ }^{57}$ See also D.J. Baker, "Foresight in Common Purpose Complicity/Joint Enterprise Complicity: It Is a Maxim of Evidence, Not a Substantive Fault Element" (Draft Chapter 2013/14: Reinterpreting Criminal Complicity, Forthcoming), available at SSRN: http://ssrn.com/abstract=2507529 (accessed 21 May 2015). However, while Baker concludes that joint enterprise liability should not be established unless it is 'shown that the accessory intended the perpetrator to perpetrate the collateral crime (should the need for it arise) for the purpose of effecting their joint enterprise' and that historically, a jury could infer from S's foresight that S 'conditionally intended the collateral crimes that resulted from the unlawful joint enterprise', my view is that liability depended, and should again depend, on whether or not the accomplice has endorsed the perpetrator's collateral crime, with foresight being part of the evidential matrix from which such endorsement can be proved.

${ }^{58}$ Likewise G. Virgo, House of Commons Justice Committee, Joint Enterprise - Eleventh Report of Session 2010-12, vol I (HC 1597, 2012) at p. 8.

59 Gnango [2011] UKSC 59, [2012] 1 A.C. 827 (SC) at [42] (Lord Phillips and Lord Judge): '[L]iability arises where (i) D1 and D2 have a common intention to commit crime A (ii) D1, as an incident of committing crime A, commits crime B, and (iii) D2 had foreseen the possibility that he might do so'.

${ }^{60}$ Wakely [1990] Crim. L.R. 119.

${ }^{61}$ Chan Wing-siu [1985] A.C. 168 (PC) 175 (Sir Robin Cooke).

${ }^{62}$ Powell [1999] 1 A.C. 1 (HL) 11 (Lord Mustill).
} 
statements - usually framed in terms of (continued) participation in the criminal enterprise 'with' or 'despite' foresight - which could be read to support either of the aforementioned positions: the issue boils down to whether or not S's (continued) participation in the joint enterprise - which comprises the actus reus element - also has a mens rea dimension (going beyond cognition): it might imply volition on S's part, in the sense that by having chosen to participate despite foresight $\mathrm{S}$ demonstrates not just a willingness to run the risk of further wrongdoing by $\mathrm{P}$, but some endorsement of the consequences foreseen as possibly resulting from P's actions. In $A$ and others, for instance, the Court of Appeal said: 'the liability of D2 in the third type of joint enterprise scenario (...) rests (...) on his having continued in the common venture of crime $A$ when he realises (even if he does not desire) that crime B may be committed in the course of it. ${ }^{63}$ Arguably, the focus here is as much on foresight (= cognitive element) as it is on S's decision (= volitional element) to remain a participant in the common criminal endeavour, so that it would not be fair to say that $\mathrm{S}$ is held to account on the basis of his foresight alone. Rather, $\mathrm{S}$ may here be held to account for his decision to remain in the enterprise, a decision which is not just constitutive of a willingness to run the risk of a harm foreseen - in which case it would still be difficult to explain why that should be sufficient to constitute the mens rea for murder - but, arguably, is constitutive of S's reconciliation to such harm. Such an understanding would go beyond recklessness (in its traditional common law sense), and whilst not amounting to intention in the common law sense either, might at least bring S's responsibility closer to one for intentional conduct.

However, there are statements in two House of Lords decisions which seem to suggest that the current law is built around an entirely foresight-centred approach to

${ }^{63} A$ and others [2010] EWCA Crim 1622, [2011] Q.B. 841 at [27], 850 (Hughes LJ). Similarly Sanghera [2012] EWCA Crim 16, [2012] 2 Cr. App. R. 17 at [90] (Aikens LJ). 
establishing S's liability. Thus, in Powell, the House of Lords concluded that 'it is sufficient to found a conviction for murder for a secondary party to have realised that in the course of the joint enterprise the primary party might kill with intent to do so or with intent to cause grievous bodily harm. ${ }^{64}$ Similarly, Lord Bingham said in the subsequent decision in Rahman that 'the touchstone [of joint enterprise liability] is one of foresight. ${ }^{65}$ Calling foresight 'sufficient' and 'the touchstone of liability' suggests that the doctrine of joint enterprise, at present, does not require a volitional mens rea element - and, indeed, no mens rea ingredient other than foresight - to establish S's liability.

Lord Steyn, in Powell, was particularly explicit that we need look no further than what S contemplated to found liability:

[F]oresight is a necessary and sufficient ground of the liability of accessories. That is how the law has been stated in two carefully reasoned decisions of the Privy Council: see Chan Wing-Sui [sic] $v$. The Queen [1985] A.C. 168 and Hui Chi-ming v. The Queen [1992] 1 A.C. $34{ }^{66}$

Indeed, some passages in Chan Wing-siu ${ }^{67}$ lend support to Lord Steyn's proposition that 'foresight is a necessary and sufficient ground' of liability. Thus, Sir Robin Cooke said in that case:

It is what the individual accused in fact contemplated that matters. (...)

The prosecution must prove the necessary contemplation beyond

\footnotetext{
${ }^{64}$ [1999] 1 A.C. 1 (HL) 27 (Lord Hutton).

${ }^{65}$ Rahman [2008] UKHL 45, [2009] 1 A.C. 129 at [11], [21]. Likewise Lord Neuberger at [103].

${ }^{66}$ [1999] 1 A.C. 1 (HL) 13 (emphasis added).

${ }^{67}$ [1985] A.C. 168 (PC).
} 
reasonable doubt, although that may be done by inference as just mentioned. If, at the end of the day and whether as a result of hearing evidence from the accused or for some other reason, the jury conclude that there is a reasonable possibility that the accused did not even contemplate the risk, he is in this type of case not guilty of murder or wounding with intent to cause serious bodily harm. ${ }^{68}$

However, an earlier passage indicates that Sir Robin Cooke may here have been using the expression 'contemplation' with a rather specific meaning:

That there is [a principle of joint enterprise] is not in doubt. It turns on contemplation or, putting the same idea in other words, authorisation, which may be express but is more usually implied. It meets the case of a crime foreseen as a possible incident of the common unlawful enterprise. The criminal culpability lies in participating in the venture with that foresight. ${ }^{69}$

In this passage, 'contemplation' is equated with 'authorisation', ${ }^{70}$ a term that seems to require more than just foresight: 'authorisation' implies approval, sanction or endorsement of the acts and consequences foreseen. Arguably, the way that 'authorisation' is further linked ('it meets the case of...') with 'participating' suggests that the expression 'participation' is here used as shorthand for a participation that gives rise to an inference of approval: in continuing to participate, the defendant shows that he has authorised (in the sense of approving or deciding to live with) the

\footnotetext{
${ }^{68}$ [1985] A.C. 168 (PC) 177-78.

${ }^{69}$ [1985] A.C. 168 (PC) 175 (emphasis added).

${ }^{70}$ A point also noted in Hui Chi-ming [1992] 1 A.C. 34 (PC) 53 (Lord Lowry). But see A. Ashworth and J. Horder, Principles of Criminal Law, 7th ed. (Oxford 2013) at p. 438: 'The element of prior agreement or "authorization" seems to be rather weak here (...)'.
} 
consequences. In other words, he has endorsed the potential outcome of P's actions, if only to achieve some other goal. On such a reading, the very concept of 'participation' would include an element of volition, and foresight, although still a necessary ingredient, would no longer be sufficient to ground S's liability.

The other case Lord Steyn cites in support of his proposition is Hui Chiming. ${ }^{71}$ Lord Lowry delivered the advice in that case. With regard to an alleged misdirection concerning joint enterprise, he observed that passages in subsequent cases which were aimed at rewording the joint enterprise principle as enunciated in Chan Wing-siu had often been misleading. In particular, Lord Lowry cites with approval a lengthy passage from Hyde $e^{72}$ in which Lord Lane CJ disapproves of the statement in Wakely $^{73}$ that " $[\mathrm{t}]$ he suggestion that a mere foresight of the real or definite possibility of violence being used is sufficient to constitute the mental element of murder is prima facie, academically speaking at least, not sufficient. ${ }^{, 74}$ Lord Lane explains that this 'passage is not in accordance with the principles set out by Sir Robin Cooke which we were endeavouring to follow and was wrong, or at least misleading. ${ }^{75}$ He goes on to offer the following reformulation of the joint enterprise principle:

If $\mathrm{B}$ realises (without agreeing to such conduct being used) that A may kill or intentionally inflict serious injury, but nevertheless continues to participate with $\mathrm{A}$ in the venture, that will amount to a sufficient mental element for $\mathrm{B}$ to be guilty of murder if $\mathrm{A}$, with the requisite

\footnotetext{
${ }^{71}$ [1992] 1 A.C. 34 (PC).

${ }^{72}$ [1991] 1 Q.B. 134 (CA).

${ }^{73}$ [1990] Crim. L.R. 119.

${ }^{74}$ [1992] 1 A.C. 34 (PC) 50 (Lord Lowry citing Lord Lane CJ in Hyde [1991] 1 Q.B. 134 (CA) 139).

${ }^{75}$ Ibid.
} 
intent, kills in the course of the venture. As Professor Smith points out, $B$ has in those circumstances lent himself to the enterprise and by so doing he has given assistance and encouragement to $A$ in carrying out an enterprise which $B$ realises may involve murder. ${ }^{76}$

This statement is not so much restating or clarifying the passage in Chan Wing-siu as putting a new gloss on the joint enterprise doctrine. Evidently, 'realisation' is a lot closer to foresight than 'contemplation'; however, the idea of the defendant having 'lent' himself to the enterprise and thereby having given assistance and encouragement clearly requires more than foresight on the part of the defendant, and may require even more than 'authorisation': it implies that the defendant, S, has somehow been instrumental ${ }^{77}$ in the commission of P's crime. The quoted passage also suggests that the defendant's mental state must relate to his being so instrumental, because it requires that he deliberately lent himself to the enterprise.

Arguably, a further passage in the judgment makes clear that the opinion in Hui Chi-ming is in fact ill-suited to support Lord Steyn's proposition. Thus, further on, Lord Lowry says the following (about the meaning of 'participation'):

This was a strong case of at least tacit agreement that Ah Hung should be attacked accompanied by foresight, as admitted by the defendant, that a very serious assault might occur, even if that very serious assault had not been planned from the beginning. It is, moreover, easier to prove against an accomplice that he contemplated and by his participation accepted the use of extra force in the execution of the

\footnotetext{
${ }^{76}$ [1992] 1 A.C. 34 (PC) 50-51 (Lord Lowry citing Lord Lane CJ in Hyde [1991] 1 Q.B. 134 (CA) 139). Emphasis added.

${ }^{77}$ Not necessarily in the sense that $\mathrm{S}$ has caused crime B.
} 
planned assault than it normally would be to show contemplation and acceptance of a new offence, such as murder added to burglary. ${ }^{78}$

Lord Lowry's words (quite clearly) suggest that the joint enterprise principle might originally have been built upon contemplation plus acceptance [by conduct] (ie participation) of the consequences foreseen. Such an acceptance clearly goes to the defendant's mental state. It is thus difficult to see how Lord Steyn's proposition that foresight is necessary and sufficient is supported by the reasoning in Hui Chi-ming. Indeed, Lord Steyn himself seems to realise that his view is not all that well supported by authority, for he continues at length to justify the imposition of liability in Powell with reference to policy and practical considerations. ${ }^{79}$

Bearing in mind how the Privy Council in the above cases initially associated 'participation' with both 'authorisation' and 'acceptance', it might be argued that, notwithstanding the fact that the language of 'authorisation' was rejected in Powell (replacing it with 'contemplation', upon which the focus in modern cases shifted to foresight), the law on joint enterprise, in continuing to rely on the "participating with foresight'-formula, still has at its core an element of volition. Ultimately $\mathrm{S}$ might thus be held to account because he has endorsed, as judged by his overall behaviour, the consequences foreseen by him as possible to result from his companion's actions.

The view put forward here is admittedly not easily reconciled with the two House of Lords decisions in Powell and Rahman. However, I have tried to demonstrate that those decisions, in turning foresight from an evidential into a substantive requirement, are based on an unsound footing in terms of authority. The

\footnotetext{
${ }^{78}$ [1992] 1 A.C. 34 (PC) 53 (emphasis added).

${ }^{79}$ Powell [1999] 1 A.C. 1 (HL) 14.
} 
Supreme Court in Jogee $e^{80}$ will have an opportunity to revisit this development. I would argue that, in Powell, the House of Lords took a wrong turn as a matter of principle and I will explain the reasons for this view in the following section.

\section{WHY ENDORSEMENT IS PREFERABLE TO MERE FORESIGHT}

There are five good reasons why the common law might want to adopt an endorsement-based approach to assessing mens rea in joint enterprise situations. First, identifying an element of endorsement provides us with a stronger link between S's conduct and P's crime B than the foresight approach and the justifications put forward to defend it which place emphasis on S's having joined $\mathrm{P}$ in the original enterprise. I will not discuss justifications based on assumption of risk, enhancement of risk, omissions-based liability, and change of normative position as I have considered these at length elsewhere, ${ }^{81}$ save to say that all these locate the crucial trigger for liability in S's commitment to and the role he plays in the initial joint enterprise (crime A); they do not point to a link between $\mathrm{S}$ and crime B other than S's having been involved in crime A with foresight of crime B. Under the endorsement approach, S would not just have to have foreseen the risk (of murder) and assessed it as more than negligible; the jury would also have to believe beyond a reasonable doubt that he had reconciled himself to his companion's murderous intent and actions and, ultimately, the victim's death. It is not doubted, of course, that foresight will have a role to play in reaching that conclusion, but the jury will have to consider it as part of the overall factual matrix. Whilst S's murder conviction would thus still not be based on intention, ${ }^{82}$ the

\footnotetext{
${ }^{80}$ [2013] EWCA Crim 1433.

${ }^{81}$ B. Krebs, “Joint Criminal Enterprise” (2010) 73(4) M.L.R. 578, 592-602.

${ }^{82}$ W. Wilson and D. Ormerod, "Simply harsh to fairly simple: joint enterprise reform" [2015] Crim. L.R. 3, 22-23 suggest that $\mathrm{S}$ should be liable for joint enterprise murder if he intended or believed that $\mathrm{P}$ would kill with murderous mens rea or intentionally cause gbh. Likewise M. Dyson, see House of Commons Justice Committee, Joint Enterprise: Follow-up - Fourth Report of Session 2014-2015
} 
endorsement test would raise the mens rea standard from what is currently a watereddown version of subjective recklessness, bringing it closer to what is required to convict the main perpetrator. It avoids the practical difficulties connected with basing liability on intention, namely that intention in the Woolin-sense is difficult to prove against secondary parties in cases in which it is often unclear who the main perpetrator even was, while making convicting the secondary party more palatable morally. S's involvement with crime A is now linked with crime B because of his reprehensible attitude towards the commission of crime B by the principal perpetrator. This is preferable to a link based on foresight alone, which, as explained above, does not provide a moral connection between $\mathrm{S}$ and crime $\mathrm{B}$.

The second good reason for preferring an endorsement-based approach to the current law is that it would make the basis of S's conviction intellectually sounder, in that endorsement can actually explain why $\mathrm{S}$ is to be held responsible for what is essentially P's crime: by his endorsement of crime B, the scope of the enterprise (crime A) is extended, so that S now has participated in a venture that includes P's further wrongdoing. In other words, the joint enterprise to which $\mathrm{S}$ is a party consists of both crime A and crime B. Endorsement thus furnishes the vital criterion by which the jury can decide whether the killing formed part of P's and S's common plan or purpose, so that it can then, justifiably, be attributed to S. If, for instance, in my 'car torching gone wrong'- example, $\mathrm{S}$ had continued to set fire to other cars after $\mathrm{P}$ had killed the intervener, it would be possible for the jury to infer that he had thereby adopted P's act of killing. ${ }^{83}$ In contrast, had S in the same situation exclaimed 'What

(December 2014), available at http://www.publications.parliament.uk/pa/cm201415/cmselect/cmjust/ 310/31002.htm (accessed 21 May 2015) at para [43].

${ }^{83}$ Thus, in Broda (25 March 2015, unreported), the Court of Appeal considered it relevant that the appellant (who had not himself taken part in the assault in question) bought beers for the active participants. 
are you doing?' in a voice of utter disbelief, this might be taken to indicate that he was not, in any sense of the word, 'okay' with what his companion, P, was doing, giving rise to an inference that he did not endorse the latter's actions, although it cannot be denied that, on the facts, he had foresight that P might do just such a thing, knowing as he did of the presence of the knife and P's violent disposition.

The endorsement approach can explain S's liability not just in joint enterprise scenarios (which, as we have seen, concern two crimes), but also in instances of 'ordinary' aiding \& abetting ${ }^{84}$ and co-perpetration (where only one crime will have been committed). Indeed, it is possible to argue that endorsement is the underlying principle of all of these forms of liability: it is required, at the very least as a necessary condition, in order to fix participants in crime with liability, be it because they encouraged another's crime, aided in its commission or actually contributed to it. The approach advocated here thus, thirdly, supports the argument that joint enterprise is not a head of liability in its own right, ${ }^{85}$ but a mechanism complementing and underlying the ordinary rules of aiding \& abetting and co-perpetration, helping to determine how far to cast the net of liability. ${ }^{86}$

\footnotetext{
${ }^{84}$ Similarly G.R. Sullivan, "Intent, Purpose and Complicity" [1988] Crim. L.R. 641, 641 who locates 'the essence of complicity not in the conduct of A but in A's attitude to the conduct of P. A's conduct becomes essentially evidence of his attitude to P's conduct, it being irrelevant that his conduct may lack any facilitative, let alone casual, impact on the commission of P's offence.' Sullivan's position however differs from the view defended in this article in that he would redefine 'the mental element in complicity to incorporate an element of purpose' (p. 642).

${ }^{85}$ See e.g. Gnango [2011] UKSC 59, [2012] 1 A.C. 827 (SC) at [45] (Lord Phillips and Lord Judge); Mendez and Thompson [2010] EWCA Crim 516 at [17] (Toulson LJ), Stringer [2011] EWCA Crim 1396, [2012] Q.B. 160 at [57] (Toulson LJ); R. Buxton, "Joint Enterprise" [2009] Crim. L.R. 233, 243; P. Mirfield, "Guilt by association: a reply to Professor Virgo", [2013] Crim. L.R. 577, 579; D. Ormerod (ed), Smith and Hogan's Criminal Law, 13th ed. (Oxford 2011) at pp. 228-230; J.C. Smith, "Criminal Liability of Accessories: Law and Law Reform" (1997) 113 L.Q.R. 453, 461-462; G. Virgo, "Making sense of accessorial liability" (2006) Archbold News 6, 9; G. Virgo, "Joint enterprise liability is dead: long live accessorial liability" Crim. L.R. [2012] 850, 865; G. Virgo, "Guilt by association: a reply to Peter Mirfield", [2013] Crim. L.R. 584, 586.

${ }^{86}$ B. Krebs, “Joint Criminal Enterprise” (2010) 73(4) M.L.R. 578, 584-592.
} 
Fourthly, the endorsement test is to be preferred to one looking to mere foresight because it excludes from the reach of the joint enterprise doctrine the case Lord Mustill found impossible to accommodate within a principle of liability which puts $\mathrm{S}$ on a par with $\mathrm{P}$, because $\mathrm{S}$ 's culpability is 'at a lower level than the culpability of the principal who actually does the deed ${ }^{87}$ : ' $\mathrm{S}$ foresees that $\mathrm{P}$ may go too far; sincerely wishes that he will not, and makes this plain to P; and yet goes ahead (...). ${ }^{, 88}$ In excluding this case, the joint enterprise doctrine becomes more coherent. It also becomes more proportionate and just in its application. This may be particularly relevant in cases in which $\mathrm{S}$ feels pressured or coerced to remain with the group notwithstanding, or even because, he foresees that conflict may escalate into (greater or even lethal) violence. The law is very clear that duress is not a defence to murder. An endorsement approach would solve this problem at the liability stage and might prevent serious injustice in such cases (by reducing S's liability to unlawful dangerous act manslaughter in appropriate cases, as will be explained below). ${ }^{89}$

Finally, all commentators seem to be agreed that the current test sets the hurdle for conviction too low, while there are fears that requiring intention would set the hurdle too high (in that it is impossible to prove in practice). Endorsement might provide a middle ground from which to work out a practicable solution.

If, as has been argued, 'participating with foresight' can be construed, or at least developed, so as to involve an element of volition (in the sense of endorsement of the foreseen harmful consequences), it would be preferable to have this articulated openly. As it is, juries struggle to make sense of the participation requirement, as evidenced, for example, by Stringer where the jury sent a note to the judge asking for

\footnotetext{
${ }^{87}$ [1999] 1 A.C. 1 (HL) 11.

${ }^{88}$ [1999] 1 A.C. 1 (HL) 11.

${ }^{89}$ See below, p. 30.
} 
clarification on what 'constituted participation as defined in his summing up'. ${ }^{90}$ It is not obvious on an 'ordinary English meaning' - interpretation of 'participation' that this requirement might aim for a finding that the defendant endorsed P's crime: while 'participating' may imply that the defendant chose to run a risk, it does not without more invite the jury to draw more far-reaching inferences as to the defendant's disposition or volitional state of mind in the sense of an acceptance of or reconciliation to the harmful consequences of P's crime. As William Wilson has pointed out, albeit in the context of homicide law reform, 'a willingness to run risks is not the same as being reconciled to their outcome', ${ }^{91}$ and it is the latter that, arguably, links S to P's crime B under the doctrine of joint enterprise, not the former (which seems ill-suited to bear the load of a murder conviction).

\section{OBJECTIONS TO AN ENDORSEMENT-BASED MENS REA APPROACH}

It might be objected that any reform along the lines suggested in this paper raises practical concerns, and in particular (1) that joint enterprise in its current form is needed to tackle gang violence effectively, (2) that the proposed change would deprive the prosecution of a bargaining chip vital in securing accomplice testimony and/or guilty pleas, and (3) that adding an element of endorsement would make jury instructions too complex. Let us take them one by one.

\section{A. Fighting Gang Violence}

Gang violence is a serious problem and one that requires a firm and effective response. Where a gang kills it may not always be easy to prove who fired the fatal shot, guided the fatal blade or landed the fatal blow. Joint enterprise as it stands

\footnotetext{
${ }^{90}$ Stringer [2011] EWCA Crim 1396, [2012] Q.B. 160 at [33].

91 W. Wilson, "Murder and the Structure of Homicide" in A. Ashworth and B. Mitchell (eds), Rethinking English Homicide Law (Oxford 2000) 21 at p. 30.
} 
makes it easy for prosecutors to avoid these problems by charging everybody involved with joint enterprise murder. It is therefore perceived to be a vital weapon in the fight against gang violence, even though its intellectual and conceptual shortcomings are, at least implicitly, acknowledged. ${ }^{92}$

It would, however, be a mistake to tackle problems created by gang membership and escalating acts of violence committed en groupe by lowering the requirements of participation and accessorial liability. ${ }^{93}$ Joint enterprise as it stands is a common law principle which as a matter of legal doctrine does not fit in well with the rest of the common law which normally insists that a defendant will only be punished according to his own moral culpability. Imposing a mandatory life sentence on a "non-acting co-adventurer' 94 merely because he foresaw that somebody else might, in the course of a joint criminal act, commit a more serious crime also raises serious rule of law concerns, in particular as to whether such a defendant is given fair warning and whether his wrongdoing is fairly labelled. The issues are wellrehearsed, ${ }^{95}$ and I do not want to repeat them here.

It is not at all obvious to me that the mens rea standard put forward in this paper, and designed to address the above concerns, would significantly weaken the

\footnotetext{
${ }^{92}$ See e.g. Lord Mustill in Powell [1999] 1 A.C. 1 (HL) 11 'Intellectually, there are problems with the concept of a joint venture (...).' For a recent overview of the problems, see W. Wilson and D. Ormerod, "Simply harsh to fairly simple: joint enterprise reform" [2015] Crim. L.R. 3.

${ }^{93} \mathrm{~W}$. Wilson and D. Ormerod also advocate a tightening of the mens rea requirement. In "Simply harsh to fairly simple: joint enterprise reform" [2015] Crim. L.R. 3, 23 they suggest that the joint enterprise law should be reformed so that ' $\mathrm{D}$ would now have to believe that $\mathrm{P}$ will intentionally kill or do GBH, or would do so if a particular condition was met. D can be legitimately labelled a murderer in either case because he lends support to a criminal venture in which death or GBH is (genuinely) an expressly or tacitly understood outcome.'

${ }^{94}$ The Law Commission, Consultation Paper No. 131, Assisting and Encouraging Crime (1993), para. [2.123].

${ }^{95}$ See e.g. House of Commons Justice Committee, Joint Enterprise - Eleventh Report of Session 201012, vol I (HC 1597, 2012) 3 at pp. 8-9, 12-15; The Bureau of Investigative Journalism, Joint Enterprise - An investigation into the legal doctrine of joint enterprise in criminal convictions (April 2014) at pp. 23-31; B. Krebs, "Joint Criminal Enterprise" (2010) 73(4) M.L.R. 578-604; W. Wilson and D. Ormerod, "Simply harsh to fairly simple: joint enterprise reform" [2015] Crim. L.R. 3.
} 
prosecution's hand. Joint enterprise based on foresight plus endorsement would still not require the prosecution to prove who committed the fatal act. In struggling to reach a verdict, however, juries would be required to consider rather more pertinent and finely tuned questions than whether or not the individual gang member foresaw that one of their number would turn lethally violent. There might, of course, be cases in which the endorsement required for joint enterprise murder cannot be proved, but this would not mean that $\mathrm{S}$ would escape liability altogether: following the Court of Appeal decision in Carpenter $^{96}$ it is arguable that a participant in crime A who foresaw at least some harm coming to the victim can be guilty of unlawful dangerous act manslaughter where P ends up killing V ${ }^{97}$ In most cases of gang violence the risk of escalation will already have been inherent in crime A. ${ }^{98}$ The advantage of this approach is that the judge will be able to sentence $S$ according to S's culpability rather than being compelled to pass a life sentence.

\section{B. Depriving the Prosecution of a Bargaining Chip}

Another objection that I have encountered in discussions is that the proposed approach would deprive the prosecution of a powerful weapon in plea bargaining and/or securing accomplice testimony. The idea is that the threat of being charged with joint enterprise murder is so powerful as to incentivise cooperation with the prosecution. However, the scope for guilty pleas under the current law is, perhaps, more limited than the general public would expect.

\footnotetext{
${ }^{96}$ Carpenter [2011] EWCA Crim 2568, [2012] Q.B. 722.

${ }^{97}$ See also W. Wilson and D. Ormerod "Simply harsh to fairly simple: joint enterprise reform" [2015] Crim. L.R. 3, 22-23. Graham Virgo advocates substituting joint enterprise murder with joint enterprise manslaughter, see "JEF 11" (written evidence submitted to the 2014 Justice Committee follow-up inquiry into joint enterprise), available at http://data.parliament.uk/writtenevidence/ committeeevidence.svc/evidencedocument/justice-committee/joint-enterprise-followup/written/ 10873.pdf (accessed 21 May 2015) at paras [15-16].

${ }^{98}$ As Lord Steyn observed in Powell [1999] 1 A.C. 1, 14: 'Experience has shown that joint criminal enterprises only too readily escalate into the commission of greater offences.'
} 
First, given that murder carries a mandatory life sentence, there is little scope for reducing the time to be served in consideration of a defendant pleading guilty. As far as the minimum prison term is concerned, the starting points are set high (whole life, 30 years, 25 years, 15 years, 12 years, depending on a number of criteria set out in Schedule 21 of the Criminal Justice Act 2003) and the maximum discount a defendant can expect in exchange for a guilty plea is one sixth of the minimum term. $^{99}$

Secondly, para 60 of the 2012 CPS Guidance on Joint Enterprise Charging Decisions appears to bar the prosecution from threatening a defendant with joint enterprise in order to secure his guilty plea on a lesser charge: 'Prosecutors should never go ahead with more charges than are necessary just to encourage a defendant to plead guilty to a few. In the same way, they should never go ahead with a more serious charge just to encourage a defendant to plead guilty to a less serious one'. ${ }^{100}$

While the Guidelines say nothing about securing accomplice testimony, there must be a serious question mark over the probative value of any accomplice testimony thus obtained. This view might be regarded as naïve and 'academic' by those actually operating the criminal justice system. It cannot be denied that the threat of being charged with joint enterprise, be it express or implied, may make it more likely that gang members will turn on other gang members. However, it is open to doubt that modifying the mental element the prosecution would be required to prove along the lines suggested would change this very much.

\footnotetext{
${ }^{99}$ W. Wilson and D. Ormerod, "Simply harsh to fairly simple: joint enterprise reform" [2015] Crim. L.R. 3, 20 .

${ }^{100}$ Note, however, that the House of Commons Justice Committee in its follow-up inquiry into Joint Enterprise found that '[p]ublication of the CPS's guidance represents a step forward, but the extent to which the guidance has improved prosecutorial practice in the way that we envisaged it might do, by reducing levels of overcharging, is open to question', see House of Commons Justice Committee, Joint Enterprise: Follow-up - Fourth Report of Session 2014-2015 (December 2014), available at http://www.publications.parliament.uk/pa/cm201415/cmselect/cmjust/310/31002.htm (accessed 21 May 2015), para [14].
} 


\section{Complexity of Jury Instructions}

One further obstacle to having an attitude-test of endorsement play a more prominent part in the mens rea of joint enterprise is the belief that the current foresight-centred approach alone is capable of keeping the mens rea inquiry in joint enterprise sufficiently simple, so that a jury comprised of non-lawyers can work with it. In Lord Mustill's words: 'What the trial judge needs is a clear and comprehensible statement of a workable principle (...).' This, however, is precisely what the current law does not provide. One only needs to look to the number of cases ${ }^{101}$ that have reached the appellate courts in recent years because of alleged misdirections ${ }^{102}$ to conclude that jury directions turning on S's foresight in joint enterprise cases are anything but uncomplicated. There is an additional problem with the supposedly simple instruction that foresight is sufficient for liability, and that is that different juries will take foresight to mean different things, with some tending to see foresight as evidence of endorsement, acquiescence or authorisation, and some taking the judge at his word, applying the foresight test literally. A little more complexity might thus not be a bad thing if it allows jury directions to lead to what juries may intuitively feel to be the just result. In fact, an analogy might be drawn with the 'moral elbow room' given to the jury by the Woollin-direction on intention with regard to finding (or denying) intention concerning the main perpetrator. In similar fashion, the endorsement test could be seen to give them an opportunity to do the morally right thing: they should

\footnotetext{
${ }^{101}$ In 2010 alone the Court of Appeal dealt with eight cases involving joint criminal enterprise.

${ }^{102}$ Recent examples include Paul [2011] All E.R. (D) 122 (Nov), where the trial judge failed to instruct the jury properly on the mental element, and Mickevicius [2012] EWCA Crim 1477, a rape by joint enterprise case, where it was found that the trial judge 'took the verdicts in a reverse order. He asked the jury for their verdicts in relation to joint enterprise before asking for their verdicts in relation to individual acts. This must have led to confusion and appears to have confused the jury', at [18] (Moses LJ).
} 
not find $\mathrm{S}$ culpable of joint enterprise murder unless they are certain beyond a reasonable doubt that $\mathrm{S}$ endorsed P's crime B.

A related objection might be that a refined mens rea standard incorporating an element of 'endorsement' would be too hard to translate into jury instructions (or 'route' or 'steps to verdict'), and that the relevant standard would, in any event, be too complex for juries to apply. However, any objection along these lines seems premised on the debateable assumption that questions of attitude are intrinsically harder to discern than questions of foresight. Arguably, in very much the same way that a person's behaviour provides some insight into his cognitive state of mind, it may tell us something about his volitional state of mind, his feelings, his dispositions, including the stance taken towards any risks and consequences foreseen, so that a person's attitude may in the end be no harder to determine than what he foresaw (and it is foresight, it should be stressed, not foreseeability, ${ }^{103}$ which is still the recognised standard of mens rea in joint criminal enterprise). Indeed, it may actually be more difficult to draw inferences as to a person's cognitive state of mind than to whether he possessed volition: as Cathleen Kaveny has argued, '[t]he materials - data, insights, and inferential reasoning - for a judgment about a defendant's foresight are typically the materials for a judgment about his intention(s), his purpose(s). Focusing on his foresight will typically be a mere detour, neither necessary nor even helpful in determining whether or not he had a murderous purpose. ${ }^{104}$

It may be too ambitious for an academic paper to make a definitive suggestion as to what a (model) jury direction on 'endorsement' might look like. It is clear,

\footnotetext{
${ }^{103}$ The 2012 Report on Joint Enterprise by the House of Commons Justice Committee describes the relevant mens rea rather inaccurately as involving a determination of 'what the offender could have anticipated or foreseen', which amounts to a foreseeability standard rather than one of actual foresight, see House of Commons Justice Committee, Joint Enterprise - Eleventh Report of Session 2010-12, vol I (HC 1597, 2012) at p. 8 (emphasis added).

${ }^{104}$ M.C. Kaveny, "Inferring Intention from Foresight" (2004) 120 L.Q.R. 81, 95.
} 
however, that it ought to mention one vital piece of information: that endorsement must not be inferred from foresight (of a risk of harm) alone (although foresight might be indicative one way or another), because if endorsement is automatically inferred from foresight, nothing of substance is added to a test which looks to foresight alone. One might invite the jury to consider not just whether the defendant foresaw the death of a third party at the hands of his associate in crime as a possible incident to their joint criminal activity, but also how he stood in relation to the risks foreseen: as a matter of inference, did the defendant, on all the evidence, by his words or conduct, by the general nature of his behaviour, taking into account all the surrounding circumstances at the time of the incident, before and during its immediate aftermath, display a particular blameworthy attitude, namely of endorsement (in the sense of acquiescence, approval, or reconciliation) towards the relevant harmful consequences?

If a judge, in whatever terms exactly, directs the jury to interpret the 'participation' requirement in the suggested way, the majority of cases that are currently dealt with under the heading of joint enterprise could still be accommodated within the refined approach. ${ }^{105}$ However, the basis of any conviction would be stronger - and intellectually sounder - in that the endorsement approach can explain why $\mathrm{S}$ is to be held responsible for P's crime: by his endorsement of crime $\mathrm{B}$, the scope of the enterprise (crime A) is extended, so that $\mathrm{S}$ now has participated in a venture that includes P's further wrongdoing. In other words, the joint enterprise to which $\mathrm{S}$ is a party consists of both crime A and crime B.

\footnotetext{
${ }^{105}$ Although in joint enterprise cases involving several defendants there usually is uncertain and/or contradictory evidence, in many appeal cases where a joint enterprise conviction has been upheld, the jury was assumed to have believed that the defendant's participation in the events went beyond mere presence at the scene with foresight. Evidence such as the defendant's chasing the victim down the road might (as seen against all the evidence) lead a jury to infer endorsement of the fatal consequences, see e.g. Rahman [2008] UKHL 45, [2009] 1 A.C. 129; Yemoh [2009] EWCA Crim 930.
} 


\section{CONCLUSION}

The doctrine of joint criminal enterprise has been criticised as unjust, over-inclusive and lacking both in clarity and principle, first and foremost because it allows for $\mathrm{S}$ to be convicted for a murder which $\mathrm{P}$ alone has committed, on the strength of S's foresight of such crime as a possible incident to their joint criminal venture, when $\mathrm{P}$ himself can only be convicted for such offence if intention is proved. The foregoing discussion has suggested that the criticisms levelled against the doctrine and, in particular, its rather undemanding mens rea standard, may be alleviated if the mental element in joint enterprise focussed not just on S's foresight, but also on his attitude vis-à-vis the consequences foreseen. On the approach here advocated, the mens rea inquiry would take into account whether $\mathrm{S}$ in fact endorsed the fatal outcome produced by his associate, be this by way of positive approval or by having reconciled himself to the foreseen consequences for the sake of achieving another goal.

It has further been argued that, inasmuch as the prevalent mens rea requirement in joint enterprise is hard to pin down and leaves room for interpretation, such an approach might already be within interpretative reach of the common law. The relevant starting point would be the well-established 'participation with foresight'-formula, the precise meaning of which remains, however, elusive: while it is commonly assumed that the mens rea standard in joint enterprise is common law recklessness, so that $\mathrm{S}$ is held liable - upon a finding of foresight and continued participation in the enterprise - for having chosen to run an unjustified risk of further wrongdoing by his associate in crime, $\mathrm{P}$, the 'participation with foresight' element, as a requirement that goes to both actus reus and mens rea, seems to allow for a more far-reaching reading, which finds support in some pre-Powell case law. As such, the expression 'participating with foresight' might be construed (or developed) so as to 
presage a requirement that $S$, by continuing to be a participant in the enterprise, has not just assumed the risk of P's further wrongdoing, but has in fact endorsed P's additional crime. On such a construction (or development), the joint enterprise doctrine would hold $\mathrm{S}$ to account on the basis of more than foresight of a possibility: S would ultimately be punished because he, in at least the weak sense of reconciliation, accepted the harm caused by his associate.

While it may not prove easy to formulate an endorsement-test for the jury to apply to a charge of joint enterprise, it has been suggested that juries can be trusted to understand the complexities of such an attitude-oriented approach to mens rea, in that it would require them to draw inferences, on all the evidence, in much the same way that people generally draw inferences about other people's feelings and mind-sets in everyday life, a task no harder to fulfil than determining what a person foresaw at any given time.

The suggested approach, in that it links S to P's further crime on the basis of S's endorsement of P's crime and its harmful consequences, would provide us with a more potent connection between $\mathrm{S}$ and P's action than the current foresight test. Indeed, it has been briefly suggested that it may be an overarching principle which applies, as a necessary condition of liability, to all forms of secondary liability and coperpetration. At the same time, the endorsement approach would allow for an exclusion of cases where the doctrine, as commonly understood, appears overinclusive, i.e. cases where $\mathrm{S}$ is expressly opposed to P's further wrongdoing, but continues to be associated with the original enterprise. ${ }^{106}$ It would also allow the jury

\footnotetext{
${ }^{106}$ Similar in outcome, if not reasoning, G. Virgo, "Joint enterprise liability is dead: long live accessorial liability" Crim. L.R. [2012] 850, 862: '[S] should not then be convicted of crime B, because his explicit rejection of it means that he is not associated with it.' See also B. Mitchell, "Participating in Homicide" in A. Reed and M. Bohlander (eds), Participation in Crime - Domestic and Comparative Perspectives (Farnham, Surrey, UK; Burlington, VT 2013) 7 at p. 13.
} 
'moral elbow room' in cases where he remains at the scene because he is being coerced or because he fears reprisals from the other members of the group should he refuse to go along with them - a particular problem for the application of the current doctrine because there is not even a partial defence of duress to murder. Such secondary parties would not necessarily escape liability for homicide, however: it may well be possible to bring home a charge of dangerous unlawful act manslaughter on the basis that the jointly committed crime A inherently came with the risk of an escalation of violence. The suggested approach would thus lead to a narrowing of the scope of the joint enterprise doctrine, whilst putting it on a principled footing.

Finally, while statutory reform in this area would be very welcome, it currently seems rather unlikely. Although the 2012 House of Commons Justice Committee Report on Joint Enterprise urged the Ministry of Justice to 'take immediate steps to bring forward legislation', ${ }^{107}$ successive Justice Secretaries have expressed little enthusiasm for taking up this advice. ${ }^{108}$ Any change must therefore, at least in the short to medium term, come from the Supreme Court, which will have an opportunity to reconsider the law in the upcoming appeal in the joint enterprise murder case of Jogee.

\footnotetext{
${ }^{107}$ House of Commons Justice Committee, Joint Enterprise - Eleventh Report of Session 2010-12, vol I (HC 1597, 2012) at p. 3.

${ }^{108}$ See n. 12 above.
} 